\title{
Література:
}

1. Новакович М. О. Канон українського музичного модернізму в творчості Бориса Лятошинського : автореф. дис... канд. мистецтвознавства: 17.00.03. Львів, 2008. 20 с.

2. Рябуха Н. О. Поетика звукового образу світу Б. Лятошинського (на прикладі фортепіанної творчості). Культура Украйни. Вип. 51. Харків, 2015. C. 26-39.

3. Хорові твори на вірші Тараса Шевченка [Ноти] / укл. А. Г. Любченко. Київ, 1989. С. 70-79.

DOI https://doi.org/10.30525/978-9934-26-004-9-131

\section{ВИКОНАВСЬКО-ТЕОРЕТИЧНІ АСПЕКТИ \\ СУЧАСНИХ АЛЬТОВИХ ТВОРІВ (НА ПРИКЛАДІ СОНАТИ ДЛЯ АЛЬТА І ФОРТЕПІАНО № 1 В. БІБІКА)}

\author{
Самокіш М. В. \\ викладач кафедри оркестрових інструментів, \\ аспірантка першого року навчання \\ Комунального вищого навчального закладу \\ «Дніпропетровська академія музики імені Михайла Глінки» \\ Дніпропетровської обласної ради» \\ м. Дніпро, Украӥна
}

У сучасних умовах формування стильових, жанрових, композиційних та виконавських засад музичного мистецтва, важливим постає питання дослідження українських сучасних творів. Насамперед, на нашу думку, це стосується альтового репертуару, що пов'язано $з$ доволі недавньою популярізацією альта у якості солюючого інструмента в порівнянні зі скрипкою та віолончеллю. Бракуванням суто альтових творів призводить до використання альтовими виконавцями репертуару, перекладеного 3 інших інструментів, що, безперечно, не завжди $є$ технологічно зручним для виконання. Невелику кількість праць, присвячених аналізу сучасних альтових українських творів, складають дослідження Косенко Г., Дедюлі Ю., Комлікової А., та інших дослідників.

Актуальність даної теми проглядається крізь призму таких чинників:

- потреба у розширенні альтового репертуару за рахунок українського сучасного репертуару; 
- недостатня ступінь дослідження та популяризації сучасного альтового репертуару, зокрема, альтових творів В. Бібіка.

- розширення професійного кругозору виконавців та музикознавців у сфері змістовної та образної семантики сучасних творів, обізнаності у сфері новітніх композиторських технік та особливостей сучасного виконавства.

Мета роботи - виявлення головних виконавсько-теоретичних аспектів сучасного українського репертуару для альта на прикладі Сонати для альта і фортепіано Валентина Бібіка № 1, здійснивши аналіз композиторських та виконавських особливостей твору.

Об'єктом дослідження є Соната для альта і фортепіано Валентина Бібіка № 1, а предметом - виконавсько-теоретичні засади твору.

Різноманіття музичних течій та стилів музичного мистецтва сьогодення пов'язане 3 жанрово - стильовим плюралізмом та інтелектуалізацією творів, що викликане новітнім композиторським мисленням. Соната для альта і фортепіано № 1 В. Бібіка - зразок сучасного розвитку виконавського та композиторського мистецтва, що проглядається крізь призму новітніх виконавських прийомів, засобів виразності, композиторських технік та оновлення музичного мистецтва в цілому. Цей твір $\epsilon$ віддзеркаленням стильової та жанрової палітри українських творів XX століття.

Соната для альта і фортепіано Валентина Бібіка № 1 була створена у 1988 році та присвячена Рівці Голані - ізраїльській альтовій виконавиці. Цей твір відрізняється прозорістю фактури та рафінованістю артикуляції, динаміки, ладотональної системи та ритмічної складової. Соната потребує від виконавця філігранності звуковидобування, відмінного володіння артикуляційною палітрою та, безумовно, новітніми техніками змістовного забарвлення семантичної платформи сучасного репертуару.

Косенко Г.Г. так характеризує особливості виконавської техніки цієї Сонати: “...альт у даному творі постійно змінюється у своїх тембрових амплуа, що зумовлює і зміну штрихів та прийомів гри, котрі виконавцю необхідно підпорядкувати загальній логіці композиційно драматургічного розвитку, представлену через цілу систему "скріплюючих" елементів у фактурі та тематиці ( наявність лейттеми, похідних лейтмотивів, тематичні “арки”, поліфонічні варіювання збільшення, зменшення, ракоходи, вертикальні та горизонтальні перестановки, полі - штрихова техніка, у тому числі, і накладення штрихів та прийомів гри в партії самого альта)'” [1, с. 149].

В основі інтонаційної складової твору лежить інтервал секунди, що $€$ характерним для творів В. Бібіка. Інтонація секунди, трансформуючись 
впродовж всього твору, набуває безмежної палітри почуттів та змістовності. В залежності від частини твору, артикуляції, темпу та регістру, образний зміст секундових інтонацій набуває розвитку від сумних та ламентозних характерів, до рішучих та емоційних закликів. Важливе семантичне значення у творі також має інтервал септіми, що використовується для підкреслення емоційного напруження, мовленнєвого звороту. Форма твору - двочастинна 3 рисами одночастинної поеми, що підтверджується головною лейттемою, яка проглядається крізь весь твір. Характерною рисою концепції форми цього твору є відсутність паузи між частинами (attaca), що додає композиційної цілісності.

Цей твір сповнений колористичних та виконавських технік, що підкреслюють приналежність твору до новітніх музичних тенденцій.

Виконавські аспекти твору включають:

- різноманітні види gliss., що у даному творі мають широке коло використання: низхідне, висхідне, з позначенням кінцевого звуку, або без нього. У деяких випадках композитор поєднує gliss. 3 cresch, dim., tr., або різноманітними ритмічними фігурами, що створює калейдоскопічну зміну образів та характерів. Цікавим прикладом звуковиражальної функції цього засобу виразності $€$ поєднання gliss. на динаміці “pp" 3 тремоло у партії альта, що звучить на фоні витриманого звуку у партії фортепіано тривалістю 15 тактів ( цифри 26, 27 другої частини Сонати).

- широке використання високого регістру альта для підкреслення емоційного напруження. Найвищий звук альтової партії у даному творі звук “соль” третьої октави ( перша частина, цифра 5).

- трелі у партіях альта та фортепіано, що використовуються у якості супроводу головної теми, - як вираження палітри колористичних та динамічних відтінків, що у деяких випадках переходять у gliss. ( друга частина, цифри $16-18 ; 23-24)$.

- використання у партії альта подвійних нот на інтервалах нони та септіми у динаміці “ff", як вираження змістовної кульмінації твору ( друга частина, цифра 23).

Теоретичні аспекти твору віддзеркалюється крізь низку таких засобів виразності, як:

- поєднання класичної та сонорної техніки звукопису

- розширена тональність твору, як засіб виразності (перша частина розширений f moll; друга - es moll)

- хроматичні інтервали, секунди та септіми, як головна складова музичної тканини

- метроритмічна та темпова гнучкість 
- багатий спектр динамічних відтінків ( від “fff” до “ppp” )

- регістрове різноманіття викладення матеріалу

-використання фермат, як відтворення образу психологізації та емоційного самозаглиблення (друга частина твору)

- прозорість фактури

- точна авторська деталізація темпових, образних та артикуляційних змін у творі. Наявність рекомендованого використання педалі у партії фортепіано та особливостей артикуляції альтової техніки

Музична мова відрізняється прозорістю та філігранністю фактури, що поєднується 3 мовленнєвими засобами сонористики. Маклигін О.: “... у першу чергу, широке застосування сонорних засобів обумовлено прагненням композиторів найбільш повно виявити і показати у всьому різноманітті картину навколишнього світу, що інтенсивно розширюється, бажання більш безпосередньо висловити різноманіття його фарб, відобразити все багатство його емоційного і духовного образу людини нашого часу" [3, с. 129 -130].

Незвичним прийомом звукопису $є$ розмежування часових пластів солюючого альта та фортепіано ( 1 частина, цифра 6 ). Фрагмент "Pochis. meno mosso" написаний з композиторською ремаркою "Ad libitum, ma agitato”. Тактові вертикалі партій фортепіано та альта не співпадають, створюючи по - справжньому агогічну та експресивно - динамічну кульмінацію першої частини твору.

Альтове музичне мистецтво, на відміну від скрипкового та віолончельного, пройшло довгий шлях свого становлення та розвитку. Альтовий виконавський стиль, формуючись під впливом переважно ансамблевої практики, є водночас універсальним та унікальним з точки зору професійних виконавсько-теоретичних засад. Купріяненко альтовим стилем вважає “сукупність специфічних якостей “образу” інструмента (матовість тембру, напруженість звучання у високому регістрі, аплікатурні складнощі у техніці виконання подвійних нот і акордів тощо), що формується у практиці ансамблевого музикування у напрямку до універсалізації його виражальних можливостей шляхом поглиблення специфіки через її подолання" [2, с. 10].

Висновок. На прикладі Сонати для альта і фортепіано №1 В. Бібіка було виявлено та досліджено новітні аспекти композиторської техніки, головні засади сучасного альтового виконавства, а саме - його технічних, звуковиражальних та художніх засад. Це дає уявлення про стан сучасного альтового мистецтва та, безумовно, розширює кордони професійного музичного мистецтва в цілому. 


\title{
Література:
}

1. Косенко Г.Г. Темброва семантика альта у творчості харківських композиторів 1960 - 2000 -х років: дис. ...канд. мистецтвознавства: 17.00.03 / Харків, Харківський нац. ун - т. мистецтв ім. Котляревського, 2018. $222 \mathrm{c}$.

2. Купріяненко Е.Б. Альт у політембровому камерно інструментальному ансамблі австро - німецької традиції (пізнє барокко Й. Брамс): автореф. дис. ... канд. мистецтвознавства. Харків, 2010. 21 с.

3. Маклыгин А. Фактурные формы сонорной музыки /сост. Ценова В.С., Сторожко Л.М. М., 1992. С. 129 -137.

DOI https://doi.org/10.30525/978-9934-26-004-9-132

\section{INITIAL POSITIONS FOR THE FORMATION OF THE PROFESSIONAL MEMORY OF A MUSICIAN-PERFORMER}

\author{
Sapsovych O. A. \\ Candidate in Art Studies, \\ Doctoral Student at the History of Music \\ and Musical Ethnography Department, \\ Associate Professor at the Special Piano Department \\ Odessa National A. V. Nezhdanova Academy of Music \\ Odesa, Ukraine
}

The professional memory of a musician-performer is one of the key phenomena that permeate all the musician's activities, starting from the very first steps in the professional field. The level of success of ones musical activity largely depends on the correctness of the algorithm of «including» various aspects of professional memory into the musician's training. It is not only about the ability to memorize, reproduce from memory and «hold in fingers» for as long as possible a musical text. Professional memory directly affects the ability to build an original interpretation, the richness of sound production, the timbre-dynamic performance capabilities, the level of virtuosity, the ability to listen and hear oneself, analyze and work constructively on one's own skill. This is a multi-component phenomenon, the various aspects of which are subdivided into interdependent facets: there is a physical level of perception, mastering and further preservation of the text, covering the auditory, visual and kinesthetic aspects, where the visual 